\title{
Analysis of Spatial Distribution of the Drought Hazard Index (DHI) by Integration AHP-GIS-Remote Sensing in Gorontalo Regency
}

\author{
Muhammad Ramdhan Olii ${ }^{1, *}$, Aleks Olii $^{1}$, Ririn Pakaya ${ }^{2}$ \\ 'Department of Civil Engineering, Universitas Gorontalo, Gorontalo, INDONESIA \\ Jalan A.A. Wahab No. 247, Limboto, Gorontalo \\ ${ }^{2}$ Department of Public Health, Universitas Gorontalo, Gorontalo, INDONESIA \\ Jalan A.A. Wahab No. 247, Limboto, Gorontalo \\ *Corresponding authors: kakaramdhanolii@gmail.com
}

SUBMITTED 24 August 2021 REVISED 22 September 2021 ACCEPTED 25 October 2021

\begin{abstract}
Several regions across the world are presently experiencing a continuous increase in water scarcity due to the rise in water consumption resulting from population development, agricultural and industrial expansion, climate change, and pollution. Droughts are increasing in recurrence, severity, duration, and spatial extent as a result of climate change. Drought will be one of the most serious threats posed by climate change, often in conjunction with other effects such as rising temperatures and shifting ecosystems. Therefore, this study analyzes the spatial distribution of the Drought Hazard Index (DHI) by integrating AHP-GIS-Remote Sensing in Gorontalo Regency. AHP was used to determine the significance of each map as an input parameter for the DHI, while GIS-Remote Sensing was utilized to supply and analyze all input maps and the study outcome. The DHI assessment consists of four criteria, namely with Normalized Difference Vegetation Index accounting for the highest proportion at 42.9\%, followed by Land Surface Temperature (33.6\%), Normalized Difference Moisture Index (16.8\%), and Topographic Wetness Index (6.7\%), with the consistency of the underlying expert opinion measured by the consistency ratio of 0.048 . The results indicated that the general hazard of drought in the Gorontalo Regency area was low $(43.53 \%)$, with $17.87 \%$ of the whole area experiencing high hazard. The high class of drought was discovered to be centered in the central region of Gorontalo Regency, which was mostly used for agricultural and economic purposes, thereby enabling policymakers to have evidence to develop management policies suitable for local conditions. Therefore, despite the limits of climatology data, this study established the value of satellite-derived data needed to support policymakers in guiding operational actions to drought hazards reduction.
\end{abstract}

KEYWORDS Analytic Hierarchy Process; Geographic Information System; Remote Sensing; Drought Hazard Index; Gorontalo Regency.

(c) The Author(s) 2022. This article is distributed under a Creative Commons Attribution-ShareAlike 4.0 International license.

\section{INTRODUCTION}

Hydrometeorological disasters are influenced by significant meteorological and weather factors, such as drought. According to (Sheffield \& Eric, 2011). Drought is a condition in an area that experiences water shortages compared to normal conditions in various hydrological cycle components. This disaster occurs in almost all parts of the world, including tropical countries such as Indonesia. Generally, drought occurs due to extreme human activities, such as land degradation, overexploitation of water, and desertification (Wijitkosum \& Sriburi, 2019). Human activities increase the risk of drought, thereby making it difficult to accurately predict its occurrence and level of hazards (Loon et al., 2016).
Drought is classified as a hydrometeorological disaster with serious environmental, social, agricultural, and economic consequences (Ekrami et al., 2016). It causes issues such as a lack of groundwater, an imbalance of water for crops, and a reduction in agricultural yields (Wu et al., 2017). Drought is influenced by natural and anthropogenic factors and seriously impacts global water and food security. Therefore, developing a thorough drought risk assessment is imperative, particularly in underdeveloped countries (Wijitkosum, 2018). In addition, conducting an assessment of the level of drought hazard in areas at risk of this disaster is very important for planning future land development, 
preventing its occurrence, and minimizing the negative impacts (Loon et al., 2016).

Drought is an inherently complex multidimensional process with unknown quantitative and qualitative factors (Wijitkosum, 2018). Real-time drought monitoring systems can analyze a large area as Remote Sensing technology, and geographic information systems (GIS) advances. These systems are increasingly being considered drought detection techniques, as evidenced by their use in many parts of the world. (Belal et al., 2012). For example, Remote Sensing data is used to calculate the Normalized Difference Vegetation Index (NDVI), Normalized Difference Wetness Index (NDWI), Land Surface Temperature (LST), Normalized Difference Built-up Index (NDBI), and Normalized Difference Moisture Index (NDMI). They are employed in the monitoring and controlling agricultural drought and crop growth (Chang, 1996; Karnieli et al., 2010; Prasetya et al., 2020; Malik et al., 2019; Sholihah et al., 2016).

Several studies developed numerous models to analyze the level of hazard, vulnerability, or risk of hydrometeorological disasters with fairly good results, such as floods, flash floods, landslides, and drought. The most widely used analysis is AHP due to its ability to determine the complexity of the factors that cause disasters. AHP-GIS is a modern graphic visualization tool used by decision-makers to disseminate and interpret spatial information on the level of hazards, vulnerabilities, and disaster risks (Patel \& Prashant, 2013; Haq et al., 2012; Chen et al., 2003; Prasad et al., 2016; Chakraborty \& Joshi, 2016; Olii et al., 2021). The Standardized Precipitation Index (SPI) is widely used for describing meteorological droughts over a wide range of timescales (McKee et al., 1993). This is in contrast to a fairly broad scale of spatial variability displayed on maps, which often contains limited information concerning localscale differences in drought severity across the area. Conversely, climate-based drought index maps are limited because they provide a generalized spatial perspective value of drought conditions and fluctuations across wide areas. However, improved and more effective drought monitoring approaches are needed to aid early warning systems. Several studies recently used AHP to analyze the level of hazard, vulnerability, and danger of drought, which yielded positive results despite the complexity of the influencing factors. (Moghari et al., 2017; Cheng \& Tao, 2010; Ekrami et al., 2016; Wijitkosum, 2018; Wijitkosum and Sriburi, 2019). In this study, GIS and Remote Sensing are integrated with mathematical models such as AHP and expected to contribute to regionbased drought analysis significantly.

This study was carried out in Gorontalo, which is one of the regencies in Gorontalo Province prone to drought. According to the Disaster Management Agency's 2019 Indonesian Disaster Risk Index, Gorontalo received a score of 104.14, therefore it is in the moderate category (13-144). The Recommendation Priority 2 (Integrated Risk Assessment and Planning) used by regencies in the moderate category is the Preparation of Risk, Hazard and Vulnerability Maps. However, the map's limitation in containing information on the distribution of the level of hazard, vulnerability, and risk of drought is one factor that hinders its ability to resolve the drought problem. It is important to determine the hazard areas of drought in order to prevent a wider impact of the disaster. Therefore, this study aims to integrate AHP, GIS, and Remote Sensing to predict the spatial distribution of drought hazard levels in Gorontalo Regency using a variety of indices, such as Land Surface Temperature (LST), Normalized Difference Vegetation Index (NDVI), Normalized Difference Moisture Index (NDMI), and Topographic Wetness Index (TWI) as references for planning, and management of drought.

\section{METHODS}

\subsection{Study Area}

Gorontalo Regency is geographically located between $0^{\circ} 28^{\prime} 23.22 "-0^{\circ} 55^{\prime} 45.08^{\prime \prime}$ North Latitude and $122^{\circ} 14^{\prime} 43.69^{\prime \prime}-123^{\circ} 4^{\prime} 48.27^{\prime \prime}$ East Longitude with a landmass of $2159 \mathrm{~km}^{2}$. The altitude ranges from 0 to 2,062 $\mathrm{m}$, with an average elevation of 50 $\mathrm{m}$ above sea level. According to a 2020 survey, the administrative area of this regency consists of 19 districts and 205 villages, with Limboto as its 
capital city. The largest and smallest districts are Asparaga and Tilango, with an area of $430.51 \mathrm{~km}^{2}$ or $20.25 \%$ and $5.79 \mathrm{~km}^{2}$ or $0.27 \%$ of the overall land area in Gorontalo Regency. This regency's northern, eastern, southern, and western parts are bordered by Gorontalo Utara, Bone Bolango Regency \& Gorontalo City, Tomini Bay, and Boalemo Regency. The highest temperature of $35.2^{\circ} \mathrm{C}$ in 2020 occurred in October, while the lowest was in September, at $18.8^{\circ} \mathrm{C}$. The highest humidity in March and June reaches 97\%, while the lowest is obtained in January, which reaches $65 \%$ in October. The highest and lowest duration of exposure was in September at $79.90 \%$ and 45.10\%. The highest rainfall occurs in December, with 27 rainy days.

\subsection{Data}

In this study, all maps were displayed in the GIS environment as raster models with the Digital elevation model (DEM), consisting of a grid size of $30 \times 30 \mathrm{~m}^{2}$ used to analyze the Topographic Wetness Index (TWI). Landsat TM 8 OLI (path 113; row 59; date acquired $=2019-12-02$; path 113; row 60 ; date acquired $=2019-12-02$ ) accessed from USGS_with a grid size of $30 \times 30 \mathrm{~m}^{2}$ was used to analyze Land Surface Temperature (LST), Normalized Difference Vegetation Index (NDVI), and Normalized Different Wetness Index (NDWI). Cloud cover of Landsat TM 8 OLI was removed by Fmask 3.2 version Windows package. Additionally, the Gorontalo Regency administrative boundaries were-downloaded from GADM.

\subsection{Methodology}

Remote Sensing is the science and art of obtaining information on an object, area, or phenomenon through the analysis of data acquired by a device that is not in contact with the object, area, or phenomenon under investigation. In this study,

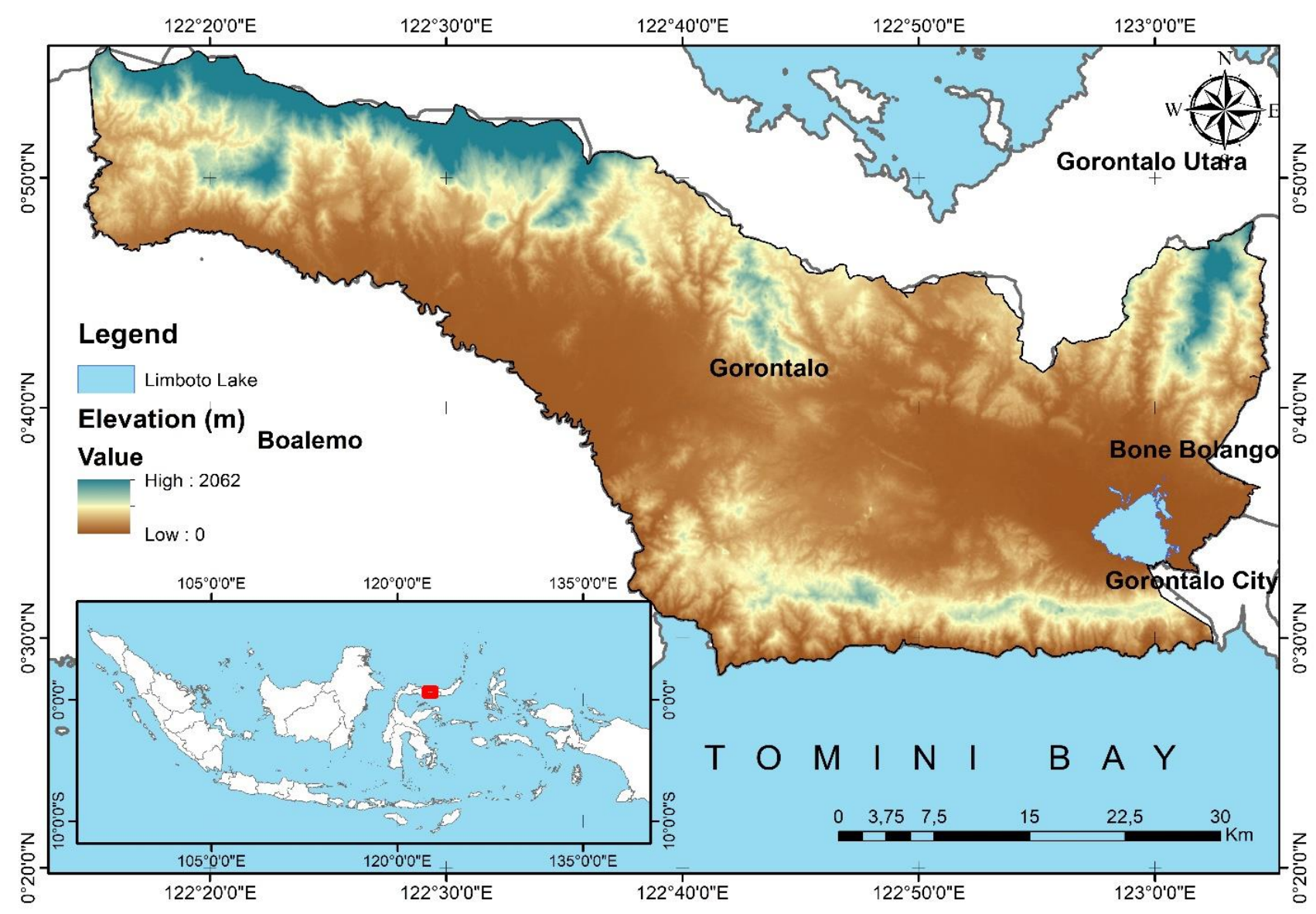

Figure 1. Location of the study area 
the factors that influence a Drought Hazard Index (DHI) such as Land Surface Temperature (LST), Normalized Difference Vegetation Index (NDVI), and Normalized Different Wetness Index (NDWI) were demarcated from Landsat TM 8 OLI image using the standard methods of visual interpretation of Remote Sensing data. Digital Terrain Analysis (DTA) calculated the Topographic Wetness Index (TWI) was calculated by Digital Terrain Analysis (DTA) using the GIS package. The overlay operation is used by most GIS, which provides information through the combination and use of several maps. During the overlay operation, new special elements are created based on multiple maps and performed using the raster, a data structure well suited for this type of operation. All of the maps used in the analysis have the same georeference and a similar number of grids organized in the same row and column. They also have the same grid size and coordinate with a program used to examine each grid when several maps are combined, thereby allowing the same figures to be checked from different maps during image combination. In a raster overlay, grid numbers are combined in a specific way, and the figures obtained are assigned to the corresponding grids in the output layer of the image. A raster overlay is applied to data that contains explicit or ordinal numbers, with each grid consisting of a string of characters. The figures in each grid correspond to the items of raster variables. Further explanation for each DHI factor is shown below.

1. Normalized Difference Vegetation Index (NDVI). This method is frequently used to measure and assess the vegetation index value of a given area. According to the NDVI analysis, green plants develop successfully by absorbing radiation in the visible light spectrum (PAR or Photosynthetically Active Radiation) and reflecting it at the nearinfrared area. The spectral pattern definition is also based on this theory in addition to the use of RED band images, Karnieli et al. (2010) discovered a clear negative relationship between NDI and LST, indicating that healthy green vegetation lowers the surface temperature. $N D V I$ is used as a response variable to identify and quantify drought disturbance in semiarid and arid lands, with low values indicating stressed vegetation (Table 1 and Figure 2) (Tucker \& Choudhury, 1987). NDVI is calculated using Equation (1) (Tucker, 1979):

$$
N D V I=\frac{N I R-R E D}{N I R+R E D}=\frac{\text { band } 5-\text { band } 4}{\text { band } 5+\text { band } 4}
$$

where $N I R$ and $R E D$ are the reflection in the near-infrared (band 5) and red range (band 4) spectrums.

2. Land Surface Temperature (LST). LST is the land's radiative skin temperature as determined by infrared radiation. It is a critical parameter in all physical processes consisting of surface energy and water balance at both local and global scales (Malik, et al, 2019; Karnieli et al., 2010). LST is necessary to land surface processes for climatic reasons and regulates sensible and latent heat flux exchange (Sun \& Pinker, 2003). It can be used in various fields, including evapotranspiration, climate change, the hydrological cycle, plant monitoring, urban climate, and environmental studies (Weng, 2009; Voogt \& Oke, 2003; Arnfield, 2003). LST classes are shown in Table 2 and Figure 3 use LANDSAT-8 with the following steps:

Conversion to Top of Atmosphere (TOA) radiance in Equation (2) (USGS, 2019).

$$
L_{\lambda}=M_{L} \times Q_{c a l}+A_{L}-O_{i}
$$

Table 1. NDVI ranges that are appropriate for the land cover classes (Akbar et al., 2019)

\begin{tabular}{llll}
\hline No. & Land Cover Class & NDVI Range & Score \\
\hline 1. & Built-Up & $0.015-0.14$ & 6 \\
2. & Barren Land & $0.14-0.18$ & 5 \\
3. & Shrub and Grassland & $0.18-0.27$ & 4 \\
4. & Sparse Vegetation & $0.27-0.36$ & 3 \\
5. & Dense Vegetation & $>0.36$ & 2 \\
6. & Water & $<0.015$ & 1 \\
\hline
\end{tabular}




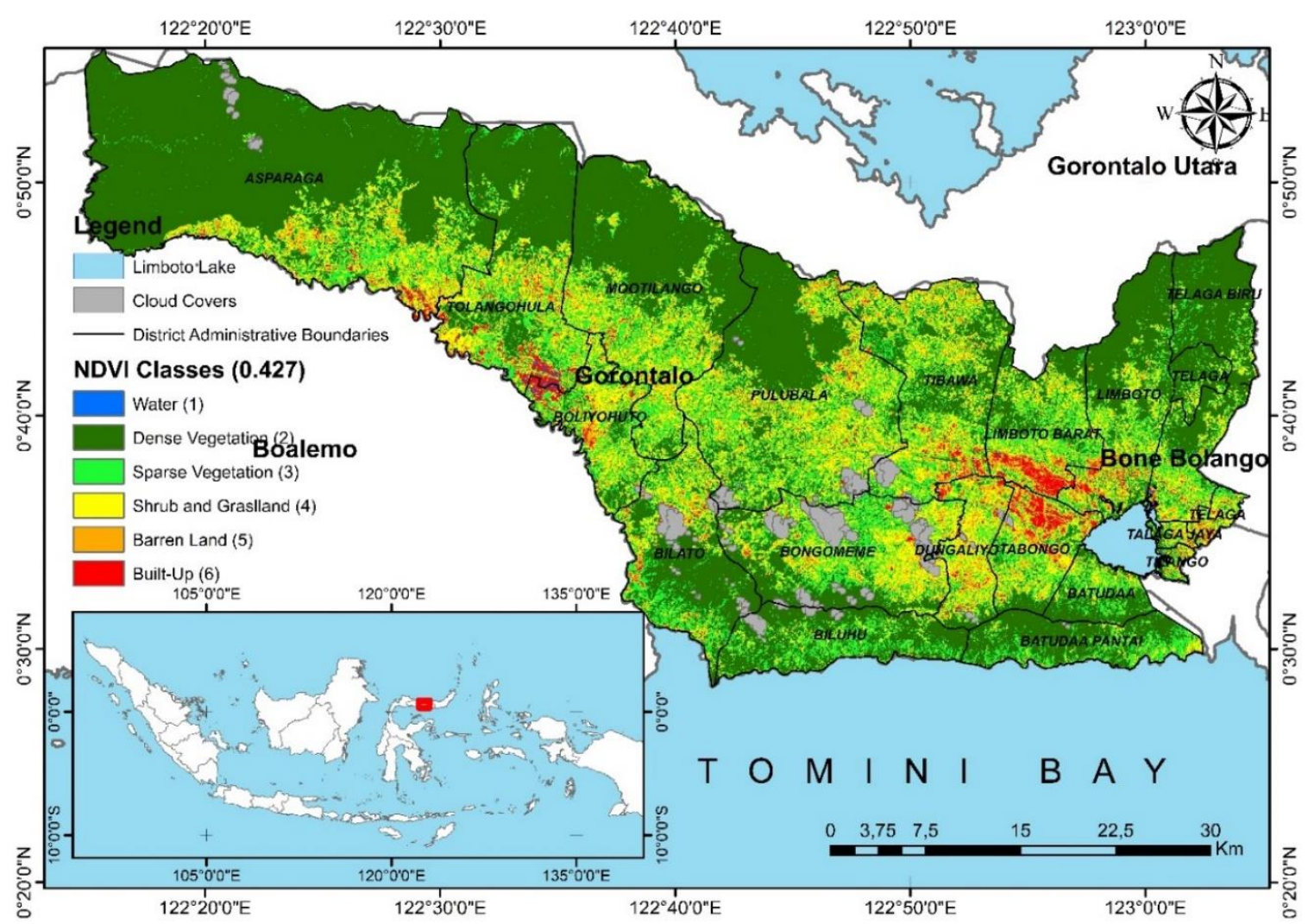

Figure 2. Normalized Difference Vegetation Index (NDVI) classes

Table 2. LST range in degree celcius (Alavipanah et al. 2017)

\begin{tabular}{lllll}
\hline No. & LST Class & LST Range & LST Range & Score \\
\hline 1. & Very Low & LST $<$ LSTmean $-1.5 \mathrm{Stdv}$ & $<20.6^{\circ} \mathrm{C}$ & 1 \\
2. & Low & LSTmean $-1.5 \mathrm{Stdv}<\mathrm{LST}<$ LSTmean - Stdv & $20.6^{\circ} \mathrm{C}-22.6^{\circ} \mathrm{C}$ & 2 \\
3. & Moderate & LSTmean - Stdv $<$ LST $<$ LSTmean + Stdv & $22.6^{\circ} \mathrm{C}-30.6^{\circ} \mathrm{C}$ & 3 \\
4. & High & LSTmean $+1.5 \mathrm{Stdv}<$ LST $<$ LSTmean $+1.5 \mathrm{Stdv}$ & $30.6^{\circ} \mathrm{C}-32.7^{\circ} \mathrm{C}$ & 4 \\
5. & Very High & $>$ LSTmean $+1.5 \mathrm{Stdv}$ & $>32.7^{\circ} \mathrm{C}$ & 5 \\
\hline
\end{tabular}

Note: LST Mean $=26.61{ }^{\circ} \mathrm{C} ;$ Stdv $($ Standart Deviation $)=4.03$

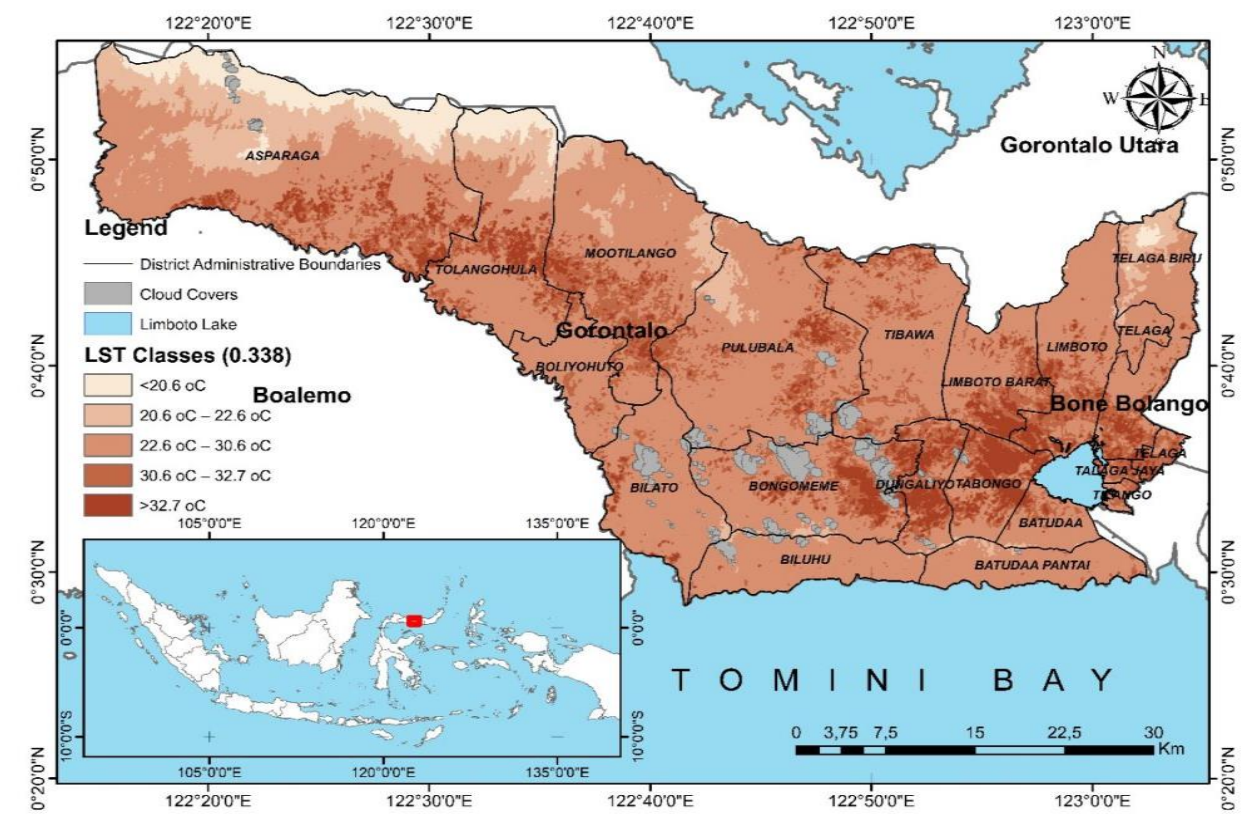

Figure 3. Land Surface Temperature (LST) classes 
where $L_{\lambda}$ is TOA spectral radiance (Watts $/ \mathrm{m}^{2} \mathrm{sr}$ $\mu \mathrm{m}), M_{L}$ is radiance multiplicative bands, $A_{L}$ is radiance add band, $Q_{c a l}$ is quantized and calibrated standard product pixel values (DN), $O_{i}$ is correction value for band 10 is 0.29 .

Conversion to Top of Atmosphere (TOA) Brightness Temperature (BT) in Equation (3) (USGS, 2019).

$B_{T}=\frac{K_{2}}{\ln \left(\frac{K_{1}}{L_{\lambda}+1}\right)}-273.15$

where $B_{T}$ denotes TOA brightness temperature (oC), $L_{\lambda}$ is TOA spectral radiance (Watts $/ \mathrm{m}^{2} \mathrm{sr}$ $\mu \mathrm{m}), K_{1}$ is $K_{1}$ constant band, and $K_{2}$ is $K_{2}$ constant band.

Proportion of Vegetation in Equation (4) (Wang et al., 2015).

$P_{V}=\left(\frac{N D V I-N D V I_{\min }}{N D V I_{\max }-N D V I_{\min }}\right)^{2}$

where $P_{V}$ denotes the proportion of vegetation, $N D V I$ is DN values of its image, $N D V I_{\max }$ and, $N D V I_{\text {min }}$ are the maximum and minimum DN values from NDVI image. Land Surface Emissivity in Equation (5) (Barsi et al., 2014)

$E=0.004 P_{v}+0.986$

where $E$ island surface emissivity, and $P_{V}$ is proportion of vegetation. Land Surface Temperature (LST) in Equation (6) (Jin et al., 2015).

$\mathrm{LST}=\frac{B_{T}}{\left(1+\left(\frac{\lambda B_{T}}{\frac{h \times c}{S}}\right) \ln (E)\right)}$

where $B_{T}$ denotes TOA brightness temperature (oC), $\lambda$ is the wavelength of emitted radiance (for band 10 is 10.8 and band 11 is 12.0), E denotes land surface emissivity, $\mathrm{h}$ is Planck's constant $(6.626 \times 10-34 \mathrm{~J} \mathrm{~s})$, s is Boltzmann constant $(1.38 \times 10-23 \mathrm{~J} \mathrm{~K})$, c is the velocity of light $(2.998 \times 108 \mathrm{~m} / \mathrm{s})$.

3. Normalized Different Moisture Index (NDMI). NDMI is calculated as the ratio of the difference and number of refracted radiations in the NIR and SWIR regions, and it is used to identify the crop's level of water stress. NDMI's absolute value allows for the interpretation of immediate identification of farm or field areas experiencing water stress. It is extremely sensitive to drought events (Hais et al., 2019) and its values range from -1 to 1 . Furthermore, each value corresponds to a different agronomic situation, irrespective of crop type, as shown in Table 3 and Figure 4. The following is the Equation (7) used to calculate NDMI (Gao, 1996).

$N D M I=\frac{N I R-S W I R 1}{N I R+S W I R 1}=\frac{\text { band } 5 \text {-band } 6}{\text { band } 5+\text { band } 6}$

where NIR is a reflection in the near-infrared spectrum (band 5), and SWIR is a reflection in the short-wave infrared of the spectrum (band 6).

Table 3. NDMI ranges are land cover classes appropriate for moisture content (Gulácsi \& Kovács 2015; Amalo et al. 2018)

\begin{tabular}{llll}
\hline No. & Land Cover Class & $\begin{array}{l}\text { NDMI } \\
\text { Range }\end{array}$ & Score \\
\hline 1. & $\begin{array}{l}\text { Very High Moisture } \\
\text { Content }\end{array}$ & $>0.7$ & 1 \\
2. & High Moisture Content & $0.6-0.7$ & 2 \\
3. & Moderate Moisture & $0.5-0.6$ & 3 \\
& Content & & \\
4. & Low Moisture Content & $0.4-0.5$ & 4 \\
5. & Weak Drought & $0.3-0.4$ & 5 \\
6. & Moderate Drought & $0.2-0.3$ & 6 \\
7. & Strong Drought & $0-0.2$ & 7 \\
8. & Very Strong Drought & $<0.0$ & 8 \\
\hline
\end{tabular}




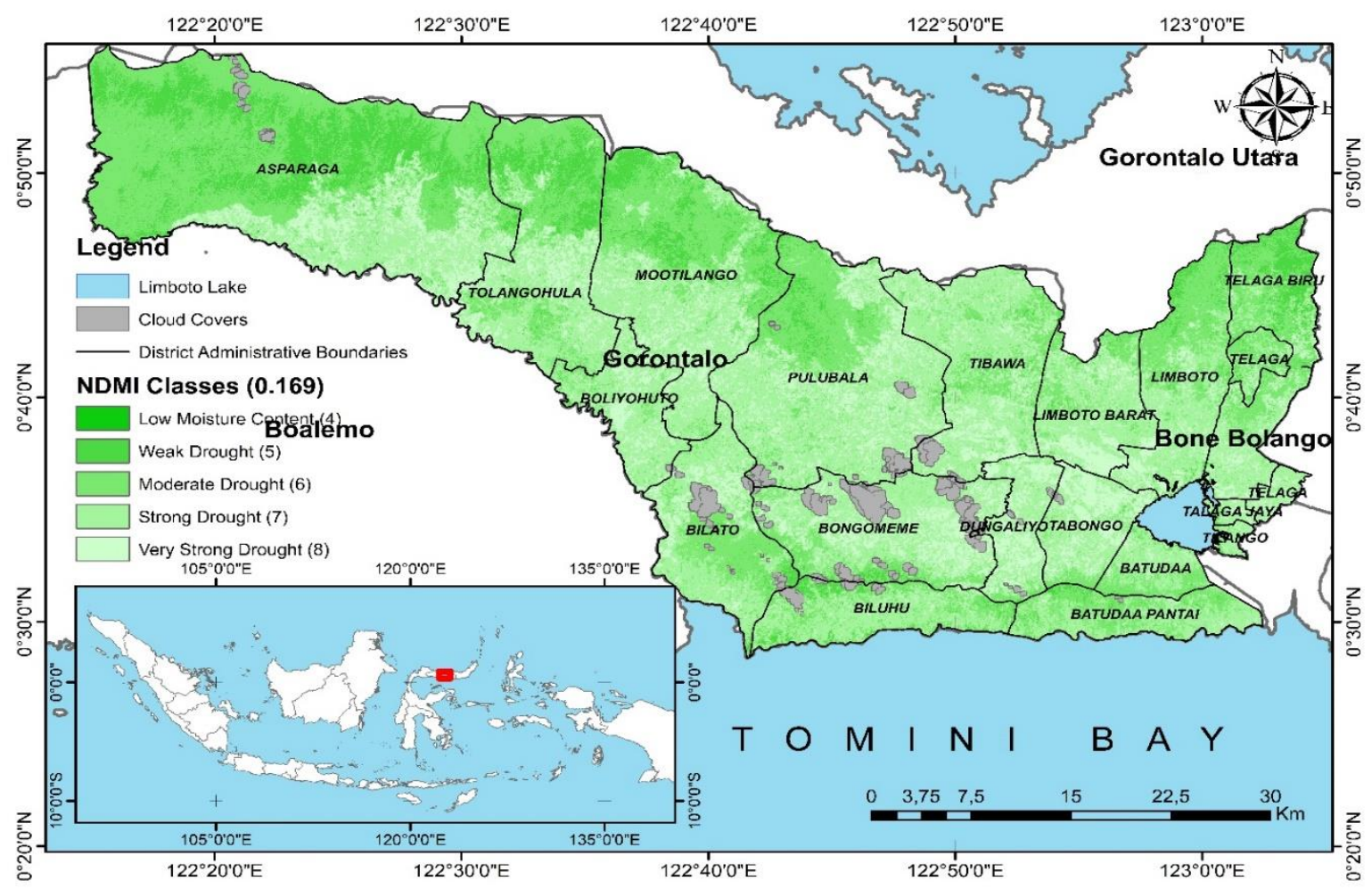

Figure 4. Normalized Different Moisture Index (NDMI) classes

4. Topographic Wetness Index (TWI). TWI predicts that a significant part of hillslope flow occurs as slope-parallel lateral, implying that flow accumulation increases with local contributing and decreases in local slopes (Beven and Kirkby, 1979). TWI is derived by integrating the upper and local slopes area, which both represent the location's wetness. It is structurally appropriate for delineating the soil wetness pattern, as shown in Table 4 and Figure 5. According to (Yang et al., 2015). TWI correlates positively with soil moisture at the soil surface of $0-1 \mathrm{~m}$. It is calculated using the following Equation (8) (Beven \& Kirkby, 1979):

$\mathrm{TWI}=\ln \left(\frac{\alpha}{\tan \beta}\right)$ where $\alpha$ is the local upslope area draining through a unit contour length, which in this study equals grid cell width, and $\beta$ is the gradient of the local slope.

Table 4. TWI ranges based on DEM (Rahmati et al., 2019)

\begin{tabular}{llll}
\hline No. & TWI Class & TWI Range & Score \\
\hline 1. & $\begin{array}{l}\text { Very Low Accumulate } \\
\text { Water }\end{array}$ & $<5$ \\
2. & $\begin{array}{l}\text { Low Accumulate } \\
\text { Water }\end{array}$ & $5-10$ & 4 \\
3. & $\begin{array}{l}\text { Moderate Accumulate } \\
\text { Water }\end{array}$ & $10-15$ & 3 \\
4. & $\begin{array}{l}\text { High Accumulate } \\
\text { Water }\end{array}$ & $15-20$ & 2 \\
5. & $\begin{array}{l}\text { Very High } \\
\text { Accumulate Water }\end{array}$ & $>20$ & 1 \\
\hline
\end{tabular}




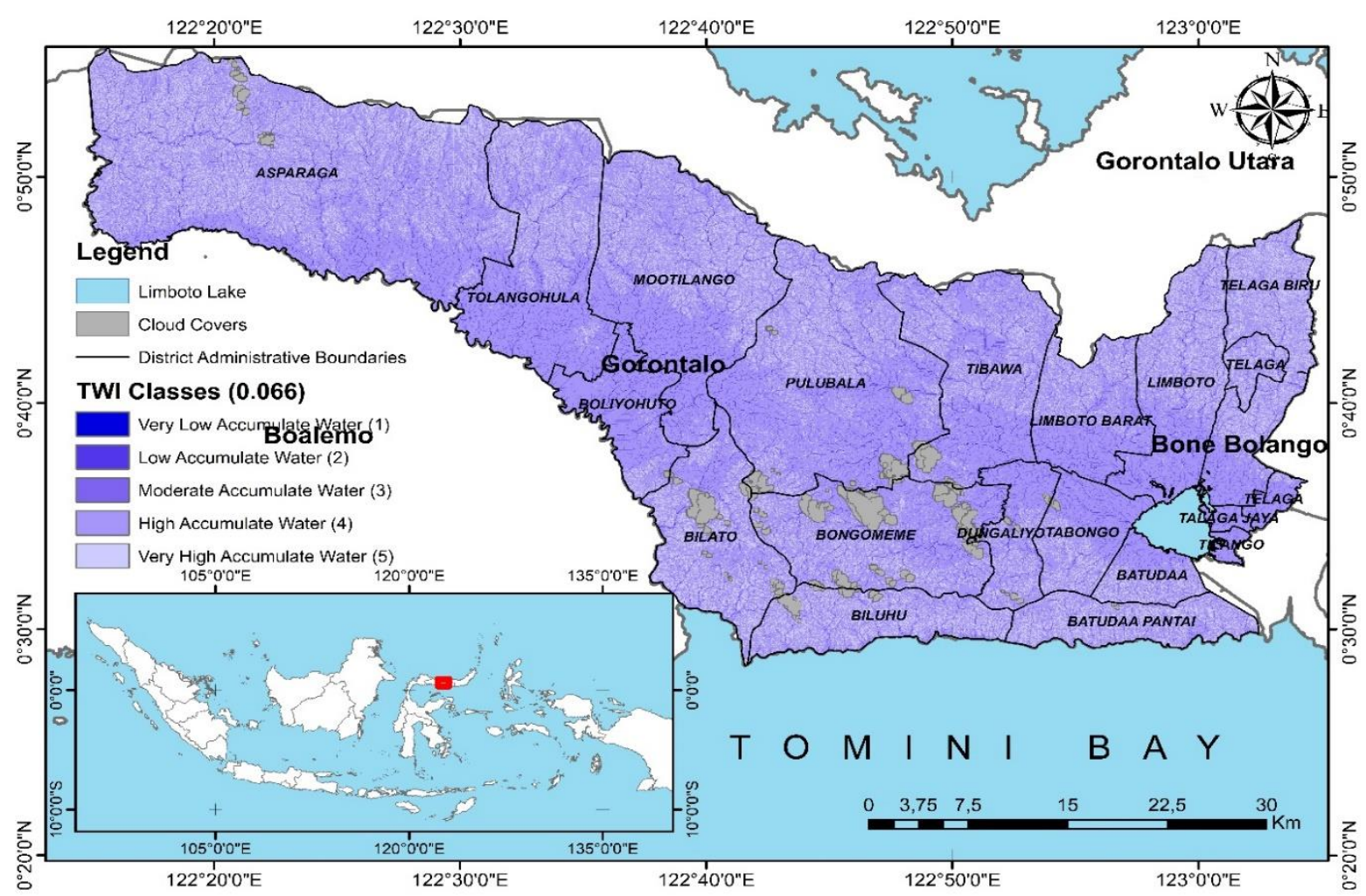

Figure 5. Topographic Wetness Index (TWI) classes

\section{ANALYTICAL HIERARCHY PROCESS (AHP) METHOD}

The Analytical Hierarchy Process (AHP) is a multicriteria decision-making technique that establishes a systematic framework for examining and integrating the effects of many factors by utilising different levels of dependent or independent qualitative and quantitative data (Saaty, 1980, 2008). This process is carried out by structurally comparing all possible paired combinations of criteria using a table-matrix with relevant values. The tool used to determine the weight of each factor is the AHP Excel Template compiled by Goepel (2013). The principle of AHP is shown in the following matrix (Saaty, 1980, 2008):

1. Determine the eigenvectors $(V p)$ of each criterion for each item, As given in Equation (9).

$$
V_{p}=\sqrt{W_{1} \times W_{2} \times W_{3} \times \ldots \times W_{n}}
$$

where $n$ denotes the number of criteria and compared $W_{\mathrm{n}}$ rating main parameters.

2. Determine the weighting coefficients $(C p)$ using the formula in Equation (10).

$$
C_{p}=\frac{V p}{V p_{1} \times V p_{3} \times V p_{3} \times \ldots \times V p_{n}}
$$

where $n$ is several criteria and $V p$ is the eigenvectors.

3. Normalize the matrix by dividing each element by the column total

4. Calculate the priority vector by averaging each line

5. To determine the overall priority, multiply each column of the matrix by the appropriate priority vector;

6. Divide each global priority by the appropriate priority vector to obtain the rational priority;

7. Calculate the consistency index $(C I)$ expressed by Equation (11).

$$
C I=\frac{\lambda_{\max }}{n-1}
$$

where $n$ is number of criteria and $\lambda_{\max }$ is the maximum eigenvalue of the comparison matrix.

8. Calculate the consistency ratio $(C R)$ using Equation (12). 


$$
C R=\frac{C I}{R I}
$$

where $R I$ is a random index that represents the consistency of a pairwise comparison matrix generated at random. Table 5 shows the average random consistency index from a sample of 500 matrixes (Saaty, 1980) When the $C R$ value is less than $10 \%$, the judgment is consistent, and the assessment requires correction when it is greater than $10 \%$.

\section{RESULTS}

AHP provides a strategy for calibrating a numerical scale by employing a pairwise methodology, which is particularly beneficial in new areas where measurements and quantitative comparisons are unavailable. All criteria's pairwise comparison matrices, as well as their weights, were computed. Elements were determined in conjunction with experts and subject matter specialists. The matrix utilized the proposed values for each factor on Saaty's scale of importance, as shown in Table 6. According to the
AHP computation results, NDVI contributes the most to DHI (42.9\%), followed by LST (33.6\%), NDMI (16.8\%), and TWI (6.7\%). Table 7 is a summary of the weights assigned to each component group and criterion.

Consistency Ratio is a CR used to construct matrices in AHP, which must be less than 0.1 to avoid reversing subjective judgments and weights. Table 8 shows the derived weights for the components, as well as the CR. These comparisons established that it is less than 0.1 , with the method's upper limit indicating that Equation (13) is credible.

$$
\begin{aligned}
D H I= & 0.429 \mathrm{NDVI}_{S} \times 0.336 L S T_{S} \times 0.168 \mathrm{NDMI}_{S} \times \\
& 0.067 T W I_{S}
\end{aligned}
$$

where $D H I, N D V I_{S}, L S T_{S}, N D M I_{S}$, and $T W I_{S}$ denote Drought Hazard Index, Normalized Difference Vegetation Index score (Table 1), Land Surface Temperature score (Table 2), Normalized Different Moisture Index score (Table 3), and Topographic Wetness Index score (Table 4).

Table 5. Random Index (RI) Value (Saaty, 1980, 2008)

\begin{tabular}{llllllllll}
\hline $\mathrm{n}$ & 1 & 2 & 3 & 4 & 5 & 6 & 7 & 8 & 9 \\
\hline $\mathrm{RI}$ & 0.00 & 0.00 & 0.58 & 0.90 & 1.12 & 1.24 & 1.32 & 1.41 & 1.45 \\
\hline
\end{tabular}

Table 6. Scale for various elements comparison (Saaty, 1980, 2008)

\begin{tabular}{lll}
\hline Intensity & Definition & Explanation \\
\hline 1 & Equal importance & Two element contribute equally to the goal \\
3 & Moderate importance & $\begin{array}{l}\text { Experience and judgement slightly favor one } \\
\text { element over another } \\
\text { Experience and judgement strongly favor one } \\
\text { element over another } \\
\text { One element is favored very strongly over another, } \\
\text { it dominance is demonstrated in practice } \\
\text { The evidence favoring one element over another is } \\
\text { of the highest possible order of affirmation }\end{array}$ \\
9 & Very strong importance & \\
\hline
\end{tabular}

Table 7. Matrix of pairwise comparisons of the criteria in relation to the goal

\begin{tabular}{llllll}
\hline Parameter & LST & NDVI & NDMI & TWI & Weight \\
\hline LST & 1 & $1 / 2$ & 3 & 5 & 0.336 \\
NDVI & 2 & 1 & 2 & 5 & 0.429 \\
NDMI & $1 / 3$ & $1 / 2$ & 1 & 3 & 0.168 \\
TWI & $1 / 5$ & $1 / 5$ & $1 / 3$ & 1 & 0.067 \\
\hline
\end{tabular}


Table 8. Parameter of Consistency Ratio

\begin{tabular}{ll}
\hline Parameter & Value \\
\hline$\lambda \max$ & 4.131 \\
$\mathrm{n}$ & 4 \\
Random Index (RI) & 0.90 \\
Mean Relative Error (MRE) & $29.5 \%$ \\
GCI & 0.17 \\
Psi & $8.3 \%$ \\
Consistency Index (CI) & 0.37 \\
Consistency Ratio (CR) & $4.8 \%$ \\
\hline
\end{tabular}

The study's primary visualization result is shown in Figure 6. This was accomplished by combining the criteria weights from Equation (13) with some GIS-related operations such as layer overlay, raster conversion, and clipping. Figure 6 is classified into 5 classes based on the likelihood of DHI, namely very low, low, moderate, high, and very high. The Natural Breaks method was used to divide the space, which compiles similar values while minimizing class differences. A total of $106,797.42$ ha, or $50.07 \%$ of the areas, were classified as having a very low or low drought hazard. A moderate drought hazard occupied up to $24.41 \%$ of the total area, while only $21.66 \%$ had a high or very high drought hazard, as shown in Table 9. Low and moderate drought occurred in the northern part of the study area and partly spread to the south, dominated by forest areas. The high drought was found to be concentrated in the central part of Gorontalo Regency, mostly used for agricultural and economic purposes (Figure 7). Therefore, the area's development needs to be carefully planned to implement drought avoidance measures. It is specifically critical in drought-prone areas to define land use and develop human activities compatible with the region's capacity.

The created DHI is an invaluable resource for risk management, damage estimation, land-use zoning, life, and property insurance claim validation, land tax valuation, lifeline emergency services, and risk reduction efforts by planning agencies and local governments. Additionally, the technique used in this study is easily transferable to other regions capable of evaluating additional criteria in accordance with data availability.

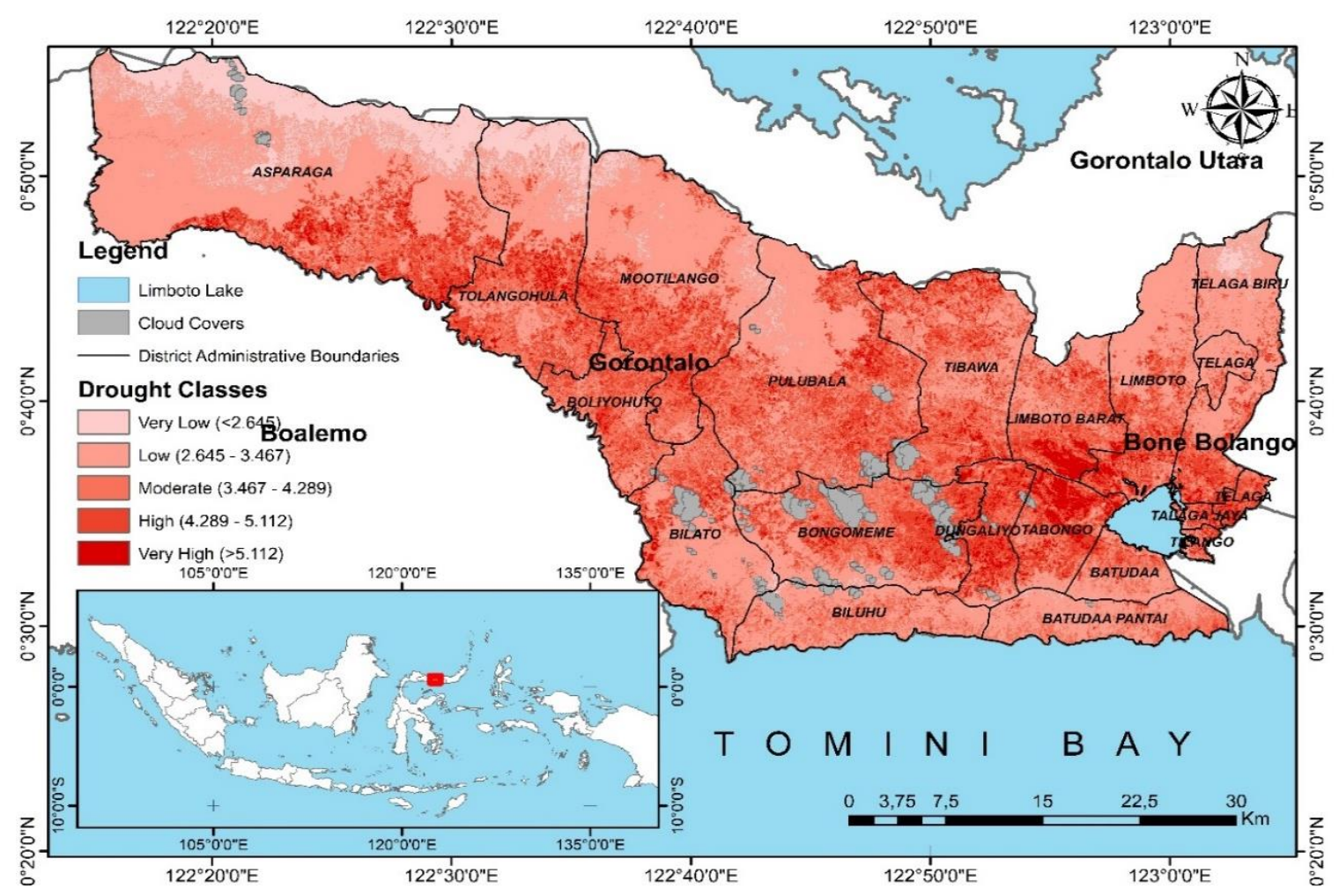

Figure 6. Distribution of drought hazard 
Table 9. Distribution of Classes of DHI in Gorontalo Regency

\begin{tabular}{llll}
\hline Classes of Drought & Range Weight & Area (Ha) & \%Area \\
\hline Very Low & $<2.645$ & $13,965.66$ & 6.55 \\
Low & $2.645-3.467$ & $92,831.76$ & 43.53 \\
Moderate & $3.467-4.289$ & $52,064.10$ & 24.41 \\
High & $4.289-5.112$ & $38,117.34$ & 17.87 \\
Very High & $>5,112$ & $8,072.28$ & 3.78 \\
Limboto Lake & - & $2,325.00$ & 1.09 \\
Cloud Cover & - & $5,903.00$ & 2.77 \\
Total & & $213,279.14$ & 100.00 \\
\hline
\end{tabular}

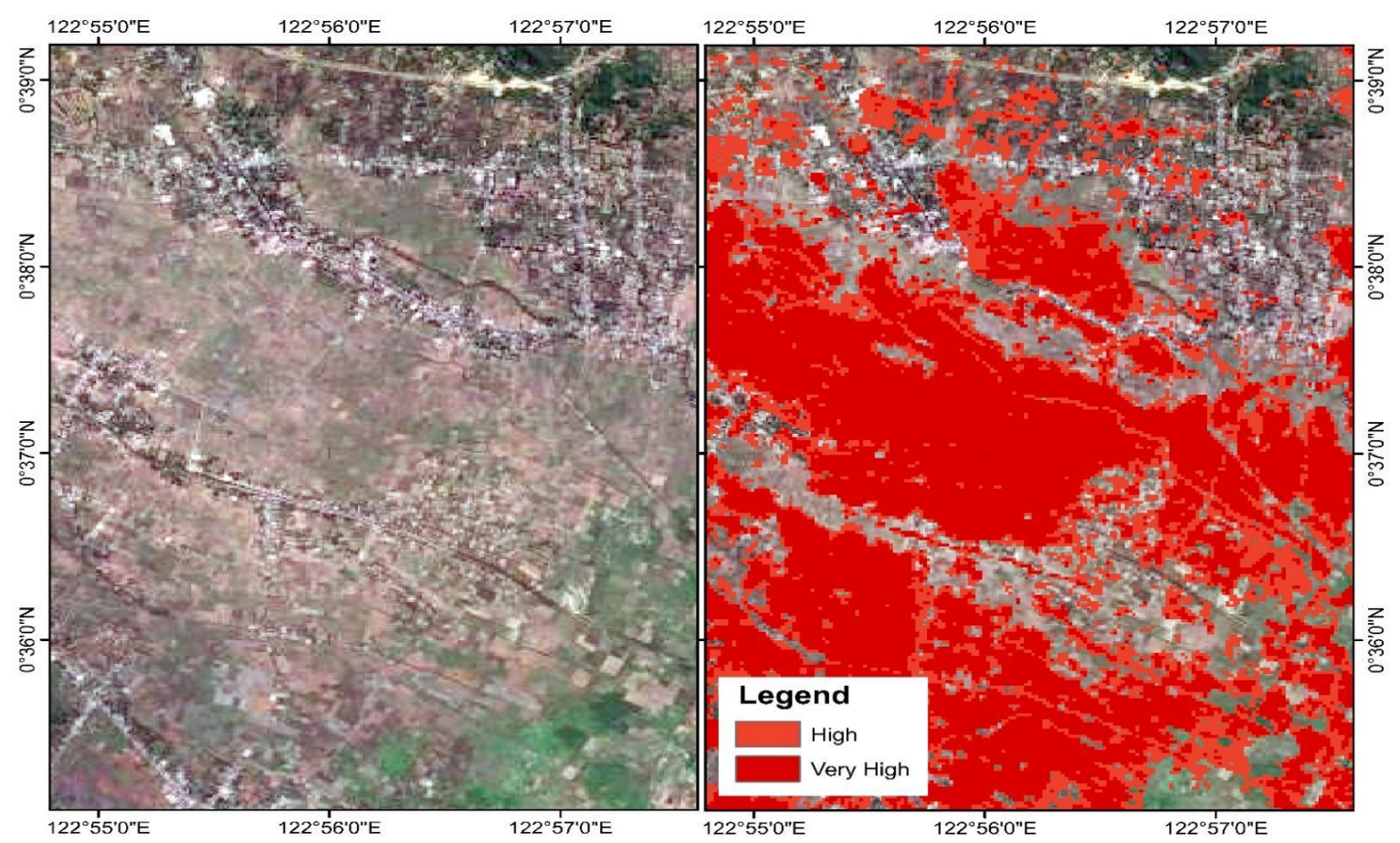

Figure 7. Comparing the distribution of high drought hazards with land use based on google earth

\section{DISCUSSION}

Several studies have been conducted on DHI in various regions around the world. However, none produced an integrated DHI map using Remote Sensing (RS), Geographic Information Systems (GIS), and Analytic Hierarchy Process (AHP). This is generally because the Indonesian National Aeronautics and Space Agency only uses a single variable, namely the Normalized Difference Vegetation Index (NDVI), and the SPI method to conduct DHI.

The method used in this study is consistent with the climatological and geomorphological parameters used in preliminary studies with the addition of Remote Sensing parameters such as LST, NDVI, and NDMI (Belal et al., 2012; Wijitkosum and Sriburi, 2019; Cheng and Tao,
2010; Moghari et al., 2017; Wijitkosum, 2018; Ekrami et al., 2016). Numerous drought studies that utilize data derived from satellites have been conducted. The Temperature Condition Index (TCI) and Normalized Difference Vegetation Index (NDVI) were developed by combining reflectance in the visible, near-infrared, and thermal bands, thereby considerably improving early drought detection, monitoring, and forecasting of its consequences on agriculture (Gebrehiwot et al., 2011; Belal et al., 2012). Study carried out by (Belal et al., 2012). successfully extended satellite data analysis to large-area vegetation monitoring and biomass productivity estimation using National Oceanic and Atmospheric Administration (NOAA) AVHRR data. Dutta et al. (2015) found that NOAA- 
AVHRR NDVI derived VCI estimates can be useful for monitoring the onset, duration, and spatialtemporal extent of agricultural drought. Meanwhile,. Rousta et al., (2020) stated that MODIS NDVI-derived from VCI with precipitation and LST images are useful for monitoring drought in Afghanistan. The relationship was negative between all NDVI categories with extreme and moderate drought conditions (Rousta et al., 2020). According to (Malik et al., 2019) the relationship between LST and NDVI has shown a strong negative correlation in summer, rainy, and winter seasons $\left(\mathrm{R}^{2}>0.9\right)$. The use of the NDVI threshold and the consideration of separating croplands from other land cover types reduces the inclusion of misclassified drought areas, thereby improving agricultural drought estimation (Faridatul \& Ahmed, 2020). The combination of the NDVI and LST provides extremely useful information for agricultural drought monitoring and early warning systems for farmers with a high negative correlation (Sruthi \& Aslam, 2015). This study found that NDVI significantly influences the DHI in Gorontalo (42.9\%) and LST (33.6\%) using 76.5\% Landsat TM 8 OLI. According to Bajgiran et al. (2008), individual metrological stations discovered substantial connections between NDVI levels and rainfall data in semiarid environments. These connections are because other local elements such as topography, soil characteristics, previous years' stress, and the area's land cover features need to be considered (Gebrehiwot et al., 2011).

NDVI and NDMI are useful for detecting and observing a specific drought area. The vegetative stress, surface water, and poor soil moisture saturation are all significant indicators used by the NDI and NDMI to detect the severity of drought in a specific area (Bhattacharya et al., 2021). These factors are useful for monitoring and assessing drought conditions in the vegetation and moisture aspects (Lin et al., 2010; Lin et al., 2011). TWI is used to confirm that hilltops are more susceptible to drought than lowlands in the catchment area, where water is more available as flow accumulates (Muukkonen et al., 2015). Furthermore, high and low TWI values represent potentially wetter and drier converging and diverging terrains (Adams et al., 2014). Bennie et al. (2008) stated that finescale topographic diversity within an area influences spatial patterns of tree development and growth responsiveness to climate. Topography influences water and energy variations throughout complicated terrain, leading to top climatic conditions and topographic gradients. These include varying levels of temperature, evapotranspiration, soil moisture, and vegetation patterns on the landscape.

Several studies on general drought hazards in various locations have been conducted in Indonesia. However, none resulted in a comprehensive drought hazard map. Therefore, this study is the first to create a drought hazard map using the GIS-RS-AHP method in Indonesia. Furthermore, meteorological stations and networks in large countries are generally insufficient and underdeveloped. The spatial resolution of rainfall data derived from these weather stations has been estimated to be greater than $100 \mathrm{~km}^{2}$ due to the sparse distribution and distance. Additionally, due to the sparse nature of infrastructure networks in major countries', continuous rainfall records are few or impossible to gather promptly. In addition, meteorological drought indices, e.g., SPI, RAI, and SPEI, have been commonly used and limited by the distribution of weather stations with the provision of only point data (Faridatul \& Ahmed, 2020). Therefore, they failed to visualize the spatial detail with the inability to determine drought susceptibility across spatial units, thereby decreasing the reliability of the drought index. In contrast, RS-based indices facilitate multitemporal drought vulnerability mapping on a regional scale. Therefore, utilizing GIS-RS-AHP to transform qualitative and quantitative factors in DHI maps was critical in fixing this issue. This is a promoting study with the ability to produce DHI maps when expanded to encompass a wider portion of the country. However, it is difficult to obtain clean data due to cloud cover, which can reduce the accuracy of the results. Therefore, a longer time span of satellite data is needed to obtain more reliable results. This means the study was unable to compare the results obtained with the drought that occurred in the field due to the 
absence of real drought disaster information. Hence, it only compared the results with google earth (Figure 7) and the drought hazard map obtained from https://inarisk.bnpb.go.id/. This map is prepared using the SPI method and divides the hazard level into 3 classes: low, medium, and high. Based on this method, Gorontalo Regency is dominated by a high level of drought hazard, which is spread in almost all regions.

\section{CONCLUSION}

In conclusion, the AHP computation results show that NDVI is the most important contributing factor to DHI, accounting for $42.9 \%$, followed by LST (33.6\%), NDMI (16.8\%), and TWI (6.7\%), at CR value of 0.048 . Areas with low, high, and very high DHI are $43.53 \%$ (9831.76 ha), $17.87 \%$, and $3.78 \%$ of the total landmass.

Remote Sensing methods that give improved realtime and spatially continuous data usable for conducting rigorous drought risk assessments across wide areas are beneficial to a country with a big land area, such as Indonesia. Satellite data can also be used to monitor droughts, provide early warnings, and mitigate the impacts of drought. In line with this, the local government or other stakeholders need to utilise a huge database to ascertain the spatial diversity of drought in the Gorontalo Regency. Additionally, these findings showed that extensive regional study is beneficial in appropriately identifying and regionalizing the drought phenomenon.

Therefore, policymakers will have evidence to develop drought management policies that are suited for local conditions. This study is also expected to highlight the critical role of satellitederived data in measuring the severity of droughts in the tropics and the tool's utility in supporting policymakers in guiding practical measures for drought hazard reduction.

\section{DISCLAIMER}

The authors declare and attest that this study is solely for academic purposes.

\section{AVAILABILITY OF DATA AND MATERIALS}

All data are available from the authors.

\section{AUTHOR CONTRIBUTION STATEMENTS}

Olii, M.R. developed the Drought Hazard Index (DHI) model using the Analytical Hierarchy Process (AHP). Olii, A., and Pakaya, R. used Remote Sensing and Geographic Information System to conduct an analytical analysis of the DHI factors. All authors made significant contributions to the discussion of the results and the writing of the manuscript.

\section{ACKNOWLEDGMENTS}

The authors are grateful to all the organizations mentioned in this study for providing the necessary data and the Engineering Faculty of Universitas Gorontalo for providing financial support through study funding

\section{REFERENCES}

Adams, H.R., Barnard, H.R. \& Loomis, A.K., 2014. Topography alters tree growth-climate relationships in a semi-arid forested catchment. Ecosphere, 5(11), pp.1-16.

Akbar, T.A., Hassan, Q.K., Ishaq, S., Batool, M., Butt, H.J. \& Jabbar, H., 2019. Investigative spatial distribution and modelling of existing and future urban land changes and its impact on urbanization and economy. Remote Sensing, 11(2).

Alavipanah, S.K., Mogaddam, M.K. \& Firozjaei, M.K., 2017. Monitoring spatiotemporal changes of heat island in Babol City due to land use changes. In: International Archives of the Photogrammetry, Remote Sensing and Spatial Information Sciences. Tehran, Iran.pp.17-22.

Amalo, L.F., Ma'Rufah, U. and Permatasari, P.A., 2018. Monitoring 2015 drought in West Java using Normalized Difference Water Index (NDWI). IOP Conference Series: Earth and Environmental Science, 149(1), pp.1-7.

Arnfield, A.J., 2003. Two decades of urban climate research: A review of turbulence, exchanges of energy and water, and the urban heat island. International Journal of Climatology, 23(1), pp.126.

Bajgiran, P.R., Darvishsefat, A.A., Khalili, A. and 
Makhdoum, M.F., 2008. Using AVHRR-based vegetation indices for drought monitoring in the Northwest of Iran. Journal of Arid Environments, 72(6), pp.1086-1096.

Barsi, J.A., Schott, J.R., Hook, S.J., Raqueno, N.G., Markham, B.L. and Radocinski, R.G., 2014. Landsat-8 thermal infrared sensor (TIRS) vicarious radiometric calibration. Remote Sensing, 6(11), pp.11607-11626.

Belal, A.A., El-Ramady, H.R., Mohamed, E.S. and Saleh, A.M., 2012. Drought risk assessment using remote sensing and GIS techniques. Arabian Journal of Geosciences, 7(1), pp.35-53.

Bennie, J., Huntley, B., Wiltshire, A., Hill, M.O. and Baxter, R., 2008. Slope, aspect and climate: Spatially explicit and implicit models of topographic microclimate in chalk grassland. Ecological Modelling, 216(1), pp.47-59.

Beven, K.J. and Kirkby, M.J., 1979. A physically based, variable contributing area model of basin hydrology. Hydrological Sciences Bulletin, 24(1), pp.43-69.

Bhattacharya, S., Halder, S., Nag, S., Roy, P.K. and Roy, M.B., 2021. Assessment of Drought Using Multi-parameter Indices. In: P.K. Roy, M.B. Roy and S. Pal, eds. Advances in Water Resources Management for Sustainable Use, 1st ed. Singapore: Springer Singapore.pp.243-255.

Chakraborty, A. \& Joshi, P.K., 2016. Mapping disaster vulnerability in India using analytical hierarchy process. Geomatics, Natural Hazards and Risk, [online] 7(1), pp.308-325. Available at: <https://doi.org/10.1080/19475705.2014.897656>.

Chang, D.Y., 1996. Applications of the extent analysis method on fuzzy AHP. European Journal of Operational Research, 95(3), pp.649-655.

Chen, K., Blong, R. and Jacobson, C., 2003. Towards an Integrated Approach to Natural Hazards Risk Assessment Using GIS: With Reference to Bushfires. Environmental Management, 31(4), pp.546-560.

Cheng, J. \& Tao, J.P., 2010. Fuzzy comprehensive evaluation of drought vulnerability based on the Analytic Hierarchy Process- An empirical study from Xiaogan City in Hubei Province. Agriculture and Agricultural Science Procedia, 1, pp.126-135.

Dutta, D., Kundu, A., Patel, N.R., Saha, S.K. and Siddiqui, A.R., 2015. Assessment of agricultural drought in Rajasthan (India) using remote sensing derived Vegetation Condition Index (VCI) and Standardized Precipitation Index (SPI). Egyptian Journal of Remote Sensing and Space Science, [online] 18(1), pp.53-63.

Ekrami, M., Marj, A.F., Barkhordari, J. \& Dashtakian, K., 2016. Drought vulnerability mapping using AHP method in arid and semiarid areas: a case study for Taft Township, Yazd Province, Iran. Environmental Earth Sciences, 75(12), pp.1-13.

Faridatul, M.I. \& Ahmed, B., 2020. Assessing agricultural vulnerability to drought in a heterogeneous environment: A remote sensingbased approach. Remote Sensing, 12(20), pp.1-17.

Gao, B.C., 1996. NDWI A Normalized Difference Water Index for Remote Sensing of Vegetation Liquid Water From Space. Remote Sensing of Environment, 58, pp.257-266.

Gebrehiwot, T., van der Veen, A. and Maathuis, B., 2011. Spatial and temporal assessment of drought in the Northern highlands of Ethiopia. International Journal of Applied Earth Observation and Geoinformation, [online] 13(3), pp.309-321. Available at: <http://dx.doi.org/10.1016/j.jag.2010.12.002>.

Goepel, K.D., 2013. Implementing the Analytic Hierarchy Process as a Standard Method for MultiCriteria Decision Making in Corporate Enterprises - a New AHP Excel Template with Multiple Inputs. In: International Symposium on the Analytic Hierarchy Process.

Gulácsi, A. \& Kovács, F., 2015. Drought Monitoring With Spectral Indices Calculated From Modis Satellite Images In Hungary. Journal of Environmental Geography, 8(3-4), pp.11-20.

Hais, M., Hellebrandová, K.N. \& Šrámek, V., 2019. 
Potential of Landsat spectral indices in regard to the detection of forest health changes due to drought effects. Journal of Forest Science, 65(2), pp.70-78.

Haq, M., Akhtar, M., Muhammad, S., Paras, S. and Rahmatullah, J., 2012. Techniques of Remote Sensing and GIS for flood monitoring and damage assessment: A case study of Sindh province, Pakistan. Egyptian Journal of Remote Sensing and Space Science, [online] 15(2), pp.135-141. Available at: <http://dx.doi.org/10.1016/j.ejrs.2012.07.002>.

Jin, M., Li, J., Wang, C. and Shang, R., 2015. A practical split-window algorithm for retrieving land surface temperature from Landsat- 8 data and a case study of an urban area in China. Remote Sensing, 7(4), pp.4371-4390.

Karnieli, A., Agam, N., Pinker, R.T., Anderson, M., Imhoff, M.L., Gutman, G.G., Panov, N. and Goldberg, A., 2010. Use of NDVI and land surface temperature for drought assessment: Merits and limitations. Journal of Climate, 23(3), pp.618-633.

Lin, M.L., Chu, C.M. \& Tsai, B.W., 2011. Drought risk assessment in western inner-mongolia. International Journal of Environmental Research, 5(1), pp.139-148.

Lin, M.L., Wang, Q., Sun, F., Chu, T.H. and Shiu, Y.S., 2010. Quick spatial assessment of drought information derived from MODIS imagery using amplitude analysis. World Academy of Science, Engineering and Technology, 43(7), pp.628-632.

Loon, A.F.V., Stahl, K., Baldassarre, D.G., Clark, J., Rangecroft, S., Wanders, N., Gleeson, T., Dijk, A.I.J.M.V., Tallaksen, L.M., Hannaford, J., Uijlenhoet, R., Teuling, A.J., Hannah, D.M., Sheffield, J., Svoboda, M., Verbeiren, B., Wagener, T. and Van Lanen, H.A.J., 2016. Drought in a human-modified world: reframing drought definitions, understanding, and analysis approaches. Hydrol. Earth Syst. Sci., 20, pp.36313650 .

Malik, M.S., Shukla, J.P. and Mishra, S., 2019. Relationship of LST, NDBI and NDVI using landsat-8 data in Kandaihimmat watershed,
Hoshangabad, India. Indian Journal of Geo-Marine Sciences, 48(1), pp.25-31.

McKee, T.B., Doesken, N.J. and Kleist, 1993. The relationship of drought frequency and duration to time scales. In: Proceedings of the Eighth Conference on Applied Climatology. Boston: American Meteorological Society.pp.179-184.

Moghari, S.M.H., Araghinejad, S.\& Azarnivand, A., 2017. Fuzzy analytic hierarchy process approach in drought management: Case study of Gorganrood basin, Iran. Journal of Water Supply: Research and Technology - AQUA, 66(3), pp.207218.

Muukkonen, P., Nevalainen, S., Lindgren, M. and Peltoniemi, M., 2015. Spatial occurrence of drought-associated damages in Finnish boreal forests: Results from forest condition monitoring and GIS analysis. Boreal Environment Research, 20(2), pp.172-180.

Olii, M.R., Olii, A. \& Pakaya, R., 2021. The Integrated Spatial Assessment of The Flood Hazard Using AHP-GIS: The Case Study of Gorontalo Regency. Indonesian Journal of Geography, 53(1), pp.126-135.

Patel, D.P. \& Prashant, S.K., 2013. Flood Hazards Mitigation Analysis Using Remote Sensing and GIS : Correspondence with Town Planning Scheme. Water Resources Management, 27, pp.2353-2368.

Prasad, A.S., Pandey, B.W., Leimgruber, W. and Kunwar, R.M., 2016. Mountain hazard susceptibility and livelihood security in the upper catchment area of the river Beas, Kullu Valley, Himachal Pradesh, India. Geoenvironmental Disasters, 3(3), pp.1-17.

Prasetya, T.A.E., Munawar, Taufik, M.R., Chesoh, S., Lim, A. and McNeil, D., 2020. Land Surface Temperature Assesment in Central Sumatra, Indonesia. Indonesian Journal of Geography, [online] 52(2), pp.239-245. Available at: $<$ http://marefateadyan.nashriyat.ir/node/150>.

Rahmati, O., Kalantari, Z., Samadi, M., Uuemaa, E., Moghaddam, D.D., Nalivan, O.A., Destouni, G. and 
Bui, D.T., 2019. GIS-based site selection for check dams in watersheds: Considering geomorphometric and topo-hydrological factors. Sustainability (Switzerland), 11(20).

Rousta, I., Olafsson, H., Moniruzzaman, M., Zhang, H., Liou, Y.A., Mushore, T.D. and Gupta, A., 2020. Impacts of drought on vegetation assessed by vegetation indices and meteorological factors in Afghanistan. Remote Sensing, 12(15), pp.1-21.

Saaty, T.L., 1980. The Analytic Hierarchy Process. New York: McGraw Hill. International.

Saaty, T.L., 2008. Decision making with the analytic hierarchy process. International Journal Services Sciences, 1(1), pp.83-98.

Sheffield, J. \& Eric, F.W., 2011. Drought: past problems and future scenarios. London, Washington D.C.: Eartscan.

Sholihah, R.I., Trisasongko, B.H., Shiddiq, D., Iman, L.S., Kusdaryanto, S., Manijo and Panuju, D.R., 2016. Identification of Agricultural Drought Extent Based on Vegetation Health Indices of Landsat Data: Case of Subang and Karawang, Indonesia. Procedia Environmental Sciences, 33, pp.14-20.

Sruthi, S. X \& Aslam, M.A.M., 2015. Agricultural Drought Analysis Using the NDVI and Land Surface Temperature Data; a Case Study of Raichur District. Aquatic Procedia, [online] 4, pp.1258-1264. Available at: <http://dx.doi.org/10.1016/j.aqpro.2015.02.164>.

Sun, D. \& Pinker, R.T., 2003. Estimation of land surface temperature from a Geostationary Operational Environmental Satellite (GOES-8). Journal of Geophysical Research: Atmospheres, 108(11), pp.1-15.

Tucker, C.J., 1979. Red and photographic infrared linear combinations for monitoring vegetation. Remote Sensing of Environment, 8(2), pp.127-150.
Tucker, C.J. \& Choudhury, B.J., 1987. Satellite remote sensing of drought conditions. Remote Sensing of Environment, 23(2), pp.243-251.

USGS, 2019. Landsat 8 Data Users Handbook. 5th ed. [online] USGS, United State: USGS. Available at:

$<$ https://landsat.usgs.gov/documents/Landsat8Da taUsersHandbook.pdf >.

Voogt, J.A. \& Oke, T.R., 2003. Thermal remote sensing of urban climates. Remote Sensing of Environment, 86(3), pp.370-384.

Wang, F., Qin, Z., Song, C., Tu, L., Karnieli, A. and Zhao, S., 2015. An improved mono-window algorithm for land surface temperature retrieval from landsat 8 thermal infrared sensor data. Remote Sensing, 7(4), pp.4268-4289.

Weng, Q., 2009. Thermal infrared remote sensing for urban climate and environmental studies: Methods, applications, and trends. ISPRS Journal of Photogrammetry and Remote Sensing, [online] 64(4), pp.335-344. Available at: $<$ http://dx.doi.org/10.1016/j.isprsjprs.2009.03.007 $>$.

Wijitkosum, S., 2018. Fuzzy AHP for drought risk assessment in lam Ta Kong watershed, the northeastern region of Thailand. Soil and Water Research, 13(4), pp.218-225.

Wijitkosum, S. and Sriburi, T., 2019. Fuzzy AHP integrated with GIS analyses for drought risk assessment: A case study from Upper Phetchaburi River Basin, Thailand. Water (Switzerland), 11(5).

Wu, J., Lin, X., Wang, M., Peng, J. and Tu, Y., 2017. Assessing agricultural drought vulnerability by a VSD Model: A case study in Yunnan Province, China. Sustainability, 9(6), pp.1-16.

Yang, L., Chen, L. and Wei, W., 2015. Effects of vegetation restoration on the spatial distribution of soil moisture at the hillslope scale in semi-arid regions. Catena, [online] 124, pp.138-146. 